Plant Tissue Cult. \& Biotech. 24(1): 57-63, 2014 (June)

$\overline{\mathrm{PTC} \& \mathrm{~B}}$

\title{
Authentication of Silybum marianum Varieties Using RAPD Analysis
}

\section{Sameh AbouZid*}

Pharmacognosy Department, Faculty of Pharmacy, Beni-Suef University, Beni-Suef 62111, Egypt

Key words: Silybum marianum, Authentication, RAPD analysis

\begin{abstract}
Silybum marianum is an important medicinal plant used for hepatic disorders. Two varieties exist for this plant $S$. marianum var. album (white-flowered) and $S$. marianum var. purple (purple-flowered). A fast and simple method (RAPD) was developed for authentication of S. marianum varieties (purple- and whiteflowered) at a DNA level. The two varieties were distinguished by polymorphic bands generated by four decamer primers, namely, OPP-10, OPG-03, OPG-01, and OPC-17. The developed RAPD method will be useful for practical authentication of $S$. marianum varieties and their adulterants.
\end{abstract}

\section{Introduction}

Milk thistle, Silybum marianum (L.) Gaertn. Asteraceae, is both an annual and a biennial herb. The plant is native to the Mediterranean and North African regions. In Egypt, purple- and white-flowered varieties of this plant species grow wild along irrigation and drainage canal banks, roadsides and waste ground (Boulos 2000). It is classified as a frequent occurring species according to ecological amplitude (Mashaly et al. 2013). The fruits of this plant yield 1.5 - 3\% of an isomeric mixture of flavonolignans collectively known as silymarin. Silymarin is known to possess hepatoprotective (Flora et al. 1998), anticancer (Deep et al. 2008), anti-inflammatory (Gupta et al. 2000), antiasthmatic (Breschi et al. 2002), anti-diabetic (Maghrani et al. 2004), immunostimulant (Alidoost et al. 2006) and hyper-prolactinemic (Capasso et al. 2009) activities. In particular, it is one of the most investigated plant extracts with known mechanisms of action for oral treatment of toxic liver damage (Polyak et al. 2010). The principal components of silymarin obtained from the fruits of the purple-flowered variety are silybin A, silybin B, isosilybin A, isosilybin B, silychristin A, silychristin B and silydianin. The flavonolignan constituents obtained from the fruits of the

*<sameh.zaid@pharm.bsu.edu.eg>. 
white-flowered variety differ from that of the purple-flowered variety (Nyiredy et al. 2008). Silandrin A, silandrin B, isosilandrin A, isosilandrin B, cissilandrin and isociscsilandrin were isolated from the methanol extract of the whiteflowered variety. It was reported that silandrin showed more effective inhibitory activity in carbon tetrachloride-treated cytotoxicity of rat hepatocytes than silybin (Hikino et al. 1984). Isosilandrin A showed a stronger inhibitory activity on the superoxide anion release by human polymorphonuclear leukocytes (Samu et al. 2004).

Recent studies have shown that DNA fingerprinting is useful in estimating genetic diversity among plant species, varieties, cultivars and populations (Lin et al. 2011, Skaria et al. 2011, Kalpana et al. 2012). RAPD is among the popular techniques used for this purpose. It is simple, fast, cheap, and needs a small amount of plant material. In RAPD analysis, genomic DNA is amplified by PCR using short primers with an arbitrary sequence resulting in multiple amplicons of different lengths that are analyzed by gel electrophoresis. This results in characteristic fingerprints of genomic DNA. Therefore, it identifies the polymorphisms of the nucleotide sequence spread randomly over the entire genome (Sucher and Carles 2008).

The aim of this study is to develop a simple and fast method for authentication and identification of genetic variation between white- and purpleflowered S. marianum varieties using RAPD analysis.

\section{Materials and Methods}

Leaves of Silybum marianum variety album (sample 1) were obtained from CairoAlexandria green road ( $140 \mathrm{Km}$ from Cairo). Leaves of S. marianum variety purple were obtained from Beni-Suef city $(120 \mathrm{Km}$ south to Cairo, sample 2$)$ and Elwasta city $(78 \mathrm{Km}$ south to Cairo, sample 3$)$. The fruits were taxonomically identified by Abdelhalim Mohamed, Flora and Phyto-taxonomy Researches Department, Horticultural Research Institute, Agricultural Research Centre, the Ministry of Agriculture, Egypt. A voucher specimen was deposited at the herbarium of Faculty of Pharmacy, Beni-Suef University.

DNA extraction was carried out using Qiagen DNeasy kit (Qiagen Santa Clara, CA). This was performed following the manufacturer's instructions as follow: a volume of $400 \mu \mathrm{l}$ of buffer AP1 and $4 \mu \mathrm{l}$ of RNase A stock solution (100 $\mathrm{mg} / \mathrm{ml}$ ) were added to a maximum of $100 \mathrm{mg}$ of ground plant tissue and vortexed vigorously. The mixture was incubated for $20 \mathrm{~min}$ at $65^{\circ} \mathrm{C}$, and mixed about two - three times during incubation by inverting tube. Buffer AP2 $130 \mu \mathrm{l}$ were added to the lysate, mixed, and incubated for $5 \mathrm{~min}$ on ice. The lysate was applied to the QIA shredder mini spin column, placed in a $2 \mathrm{ml}$ collection tube 
and centrifuged for $2 \mathrm{~min}$ at $14000 \mathrm{rpm}$. Flow-through fraction from the previous step was transferred to a new tube without disturbing the cell-debris pellet. About 1.5 volumes of buffer AP3/E were added to the cleared lysate and mixed by pipetting. A volume of $650 \mu \mathrm{l}$ of the mixture from the previous step, including any precipitate which may have been formed, were applied to the DNeasy mini spin column sitting in a $2 \mathrm{ml}$ collection tube, centrifuged for $1 \mathrm{~min}$ at $>8000 \mathrm{rpm}$ and the flow-through was discarded. This was repeated with the remaining samples. The flow-through and collection tubes were discarded. DNeasy mini spin column was placed in a new $2 \mathrm{ml}$ collection tube, $500 \mu \mathrm{l}$ buffer AW was added to the DNeasy mini spin column and centrifuged for $1 \mathrm{~min}$ at $>8000 \mathrm{rpm}$. The flow-through was discarded and the collection tube was re-used in the next step. Buffer AW $500 \mu \mathrm{l}$ was added to the DNeasy mini spin column and centrifuged for $2 \mathrm{~min}$ at $14000 \mathrm{rpm}$ to dry the membrane. The DNeasy mini spin column was transferred to a $1.5 \mathrm{ml}$ microcentrifuge tube and $100 \mu \mathrm{l}$ of buffer AE was pipetted directly onto the DNeasy membrane. The microcentrifuge tube was incubated for $5 \mathrm{~min}$ at room temperature $\left(15-25^{\circ} \mathrm{C}\right)$ and then centrifuged for 1 min at $>8000 \mathrm{rpm}$.

DNA concentration was determined by diluting the DNA $1: 5$ in $\mathrm{dH}_{2} \mathrm{O}$. The DNA samples were electrophoresed in $0.7 \%$ agarose gel against $10 \mu \mathrm{g}$ of a DNA size marker (Lambda DNA digested with HindIII and Phi x174 DNA digested with HaeIII). This marker covers a range of DNA fragments size between 23130 and $310 \mathrm{bp}$, and a range of concentrations between 95 and $11 \mathrm{ng}$. Thus, estimation of the DNA concentration in a given sample was achieved by comparing the degree of fluorescence of the unknown DNA band with the different bands in the DNA size marker.

The amplification reaction was carried out in $25 \mu \mathrm{l}$ reaction volume containing $1 \mathrm{X}$ PCR buffer, $1.5 \mathrm{mM} \mathrm{MgCl} 2,0.2 \mathrm{mM}$ dNTPs, $1 \mu \mathrm{M}$ primer, $1 \mathrm{U}$ Taq DNA polymerase and $25 \mathrm{ng}$ template DNA. PCR amplification was performed in a Perkin-Elmer/GeneAmp ${ }^{\circledR}$ PCR System 9700 (PE Applied Biosystems) programmed to fulfill 40 cycles after an initial denaturation cycle for $5 \mathrm{~min}$ at $94^{\circ} \mathrm{C}$. Each cycle consisted of a denaturation step at $94^{\circ} \mathrm{C}$ for $1 \mathrm{~min}$, an annealing step at $36^{\circ} \mathrm{C}$ for $1 \mathrm{~min}$, and an elongation step at $72^{\circ} \mathrm{C}$ for $1.5 \mathrm{~min}$. The primer extension segment was extended to $7 \mathrm{~min}$ at $72^{\circ} \mathrm{C}$ in the final cycle. The amplification products were resolved by electrophoresis in a $1.5 \%$ agarose gel containing ethidium bromide $(0.5 \mu \mathrm{g} / \mathrm{ml})$ in 1 X TBE buffer at 95 volts. The PCR products were visualized on UV light and using a Polaroid camera. Amplified products were visually examined and the presence or absence of each size class was scored as 1 or 0 , respectively. 
The banding patterns generated by RAPD-PCR marker analyses were compared to determine the genetic relatedness. Clear and distinct amplification products were scored as ' 1 ' for presence and ' 0 ' for absence of bands. Bands of the same mobility were scored as identical. The genetic similarity coefficient (GS) between the three samples was estimated according to Dice coefficient (Sneath and Sokal 1973):

Dice formula: $G S i j=2 a /(2 a+b+c)$

where GSij is the measure of genetic similarity between individuals $i$ and $j$, a is the number of bands shared by $i$ and $j, b$ is the number of bands present in $i$ and absent in $j$, and $c$ is the number of bands present in $j$ and absent in $i$.

\section{Results and Discussion}

Silybum marianum varieties album (white-flowered) and purple (purple-flowered) samples were collected from three different locations in Egypt. Sample 1 belongs to the variety album and samples 2 and 3 belong to the variety purple. Twelvedecamer primers were used to analyze the genetic variation between the two varieties (Table 1). The PCR conditions for the RAPD analysis was optimized since it can affect the pattern of PCR products. The optimized conditions were

Table 1. Sequence of the arbitrary primers assayed in RAPD-PCR.

\begin{tabular}{ll}
\hline Primer & Sequence $\left(5^{\prime}-3\right.$ ') \\
\hline OPP-10 & TCCCGCCTAC \\
OPG-03 & GAGCCCTCCA \\
OPG-01 & CTACGGAGGA \\
OPG-16 & AGCGTCCTCC \\
OPC-17 & TTCCCCCCAG \\
OPB-16 & TTTGCCCGGA \\
OPG-05 & CTGAGACGGA \\
OPM-16 & GTAACCAGCC \\
OPZ-08 & GGGTGGGTAA \\
OPZ-04 & AGGCTGTGCT \\
OPP-01 & GTAGCACTCC \\
OPM-10 & TCTGGCGCAC \\
\hline
\end{tabular}

as follows: $25 \mathrm{ng}$ DNA, $1 \mathrm{U}$ ExTaq polymerase, 40 cycles, and $36^{\circ} \mathrm{C}$ annealing temperature. S. marianum var. album and var. purple were discriminated by polymorphic bands generated by the primers OPP-10, OPG-03, OPG-01, and OPC-17 (Fig. 1). The fragment pattern of $S$. marianum var. album after amplification with the OPP-10 primer contained characteristic 600 and $1000 \mathrm{bp}$ bands. Similarly, amplification with the OPG-03 primer contained a characteristic 
$1000 \mathrm{bp}$ band, and with the OPC-17 primer contained a characteristic $300 \mathrm{bp}$ band. These fragments were absent in the profile of S. marianum var. purple. On the other hand, the fragment pattern developed after amplification with the OPG-01 primer contained a characteristic $980 \mathrm{bp}$ band with samples 2 and 3 representing $S$. marianum var. purple. Therefore, these fragments could be useful in discriminating the two varieties.

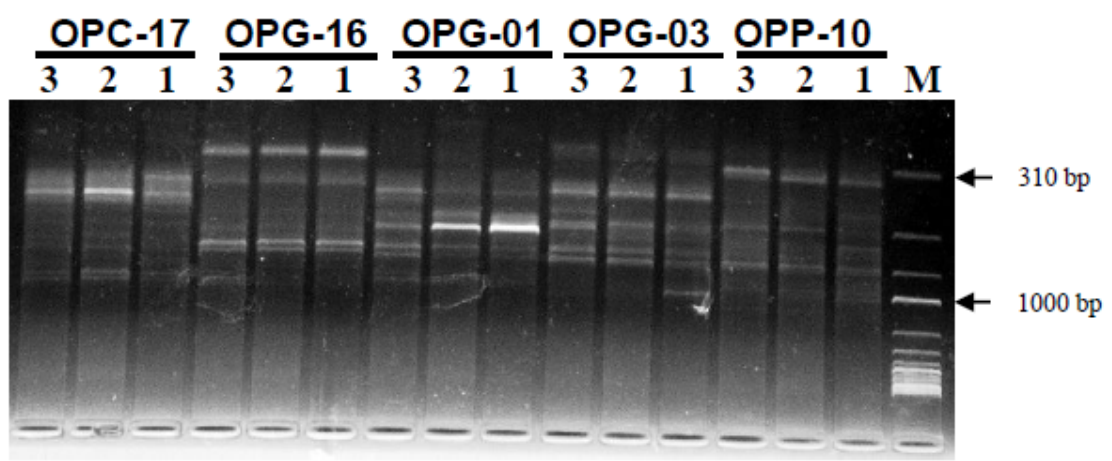

Fig. 1. RAPD patterns of Silybum marianum samples generated by primers: OPP-10, OPG03, OPG-01, OPG-16, and OPC-17. Samples 1: white-flowered S. marianum, 2 and 3: purple-flowered S. marianum.

The genetic similarity coefficient between the samples was estimated according to Dice coefficient. The similarity between the three samples was used in the cluster analysis. At the first step, when each accession represents its own cluster, the distances between these accessions are defined by the chosen distance measure (Dice coefficient). However, once several accessions have been linked together, the distance between two clusters is calculated as the average distance between all pairs of accessions in the two different clusters. This method is called Unweighted Pair Group Method using Arithmetic Average (UPGMA) (Sneath and Sokal 1973). This results in clustering of the three samples in a dendrogram (Fig. 2). The dendrogram shows the narrow genetic variation between the two varieties. Sample 1 (S. marianum var. album) had 95 and 93\% similarity with samples 2 and 3, respectively (S. marainum var. purple).

The RAPD analysis has been widely used to study genetic variation of species, varieties, cultivars and populations. The technique has been used for a number of medicinal plants. For example, genetic variation within eight varieties of Zingiber officinales (ginger) was identified using RAPD markers (Palai et al. 2007). The study showed the distant variation within the varieties, which would help in ginger improvement programs. The RAPD technique has been used for identification of ginseng plants within the Panax species using a 20 mer-random primer (Um et al. 2001). The technique has efficiently discriminated Angelica species and varieties using a decamer primer (Matsubara et al. 2013). Moreover, 
this allowed the elucidation of the origins of both A. acutiloba varieties acutiloba and sugiyamae.

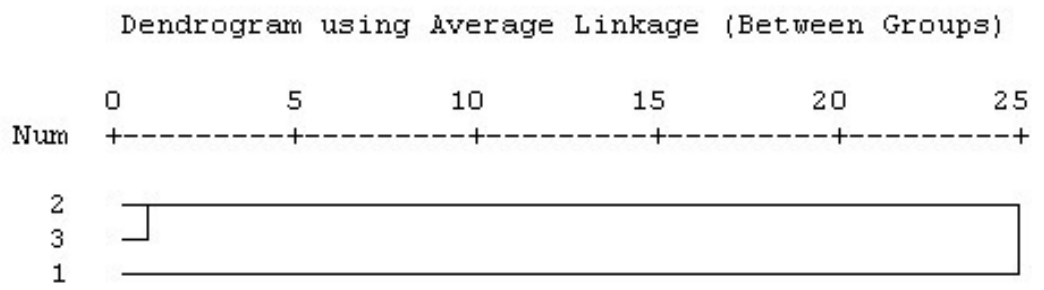

Fig. 2. Dendrogram of Silybum marianum samples 1 (white-flowered), 2 and 3 (purpleflowered) analyzed by RAPD.

The present study shows the discrimination of white-flowered and purpleflowered S. marianum varieties. The RAPD analysis shows narrow genetic variation between the two varieties. Genetic method has many advantages for identification of the two varieties over morphological method that is only possible at the flowering stage or chemical method that requires the availability of standards. It is a fast method; DNA can be isolated from fresh and dried plant parts, and it only requires small amount of the plant material. Genetic authentication may provide a reliable method in quality control programs of this pharmaceutically important plant.

\section{Acknowledgments}

The author would like to appreciate the support by the Science and Technology Development Fund (STDF), Egypt, within the framework of the "Short Term fellowship program" project ID 6081.

\section{References}

Alidoost F, Gharagozloo M, Bagherpour B, Jafarian A, Sajjadi SE, Hourfar H and Moayedi B (2006) Effects of silymarin on the proliferation and glutathione levels of peripheral blood mononuclear cells from $\beta$-thalassemia major patients. Int. J. Immunopharmacol. 6: 1305-1310.

Boulos L (2000) Flora of Egypt. (1 ${ }^{\text {st }}$ Ed) Al Hadara Publishing Inc., Cairo, Egypt.

Breschi MC, Martinotti E, Apostoliti F and Nieri P (2002) Protective effect of silymarin in antigen challenge- and histamin-induced brochoconstriction in in vivo guinea-pigs. Eur. J. Pharmacol. 437: 91-95.

Capasso R, Aviello G, Capasso F, Savino F, Isso AA, Lembo F and Borrelli F (2009) Silymarin BIO-C ${ }^{\circledR}$, and extract from Silybum marianum fuits, induces hyperprolactinemia in intact female rats. Phytomed. 16: 839-844.

Deep G, Oberlies NH, Kroll DJ and Agarwal R (2008) Identifying the differential effects of silymarin constituents on cell growth and cell cycle regulatory molecules in human prostate cancer cells. Int. J. Cancer 123: 41-50. 
Flora K, Hahn M, Rosen H and Benner K (1998) Milk thistle (Silybum marianum) for the therapy of liver disease. Am. J. Gastroenterol. 93: 139-143.

Gupta OP, Sing S, Bani S, Sharma N, Malhotra S, Gupta BD, Banerjee SK and Handa SS (2000) Antiinflammatory and antiarithritic activities of silymarin acting through inhibition of 5-lipoxygenase. Phytomed. 7: 21-24.

Hikino H, Kiso Y, Wagner H and Fiebig M (1984) Antihepatotoxic actions of flavonolignans from Silybum marianum fruits. Planta Med. 50: 248-250.

Kalpana D, Choi SH, Choi TK, Senthil K and Lee YS (2012) Assessment of genetic diversity among varieties of mulberry using RAPD and ISSR fingerprinting. Sci. Hort. 134: 79-87.

Lin J, Wang XC, Chang YH and Fang JG (2011) Development of a novel and efficient strategy for practical identification of Pyrus spp. (Rosaceae) cultivars using RAPD fingerprints. Genet. Mol. Res. 10: 932-942.

Maghrani M, Zeggwagh NA, Lemhadri A, EI Amraoui M, Michael JB and Eddouks M (2004) Study of the hypoglycaemic activity of Fraxinus excelsior and Silybum marianum in an animal model of type 1 Diabetes mellitus. J. Ethnopharmacol. 91: 309-316.

Mashaly IA, El-Shahaby OA and El-Ameir YA (2013) Floristic feature of the canal bank habitats. Egypt. J. Environ. Sci. 39: 438-501.

Matsubara K, Shindo S, Watanabe H and Ikegami F (2013) Authentication and genetic origin of medicinal Angelica acutiloba using random amplified polymorphic DNA analysis. Am. J. Plant Sci. 4: 269-273.

Nyiredy S, Samu Z, Szücs Z, Gulácsi K, Kurtán T and Antus S (2008) New insight into the biosynthesis of flavanolignans in the white-flowered variant of Silybum marianum. J. Chromatographic Sci. 46: 93-96.

Palai SK and Rout GR (2007) Identification and genetic variation among eight varieties of ginger by using random amplified polymorphic DNA markers. Plant Biotechnol. 24: 417-420.

Polyak SJ, Morishima C, Lohmann V, Pal S, Lee DY, Liu Y and Oberlies NH (2010) Identification of hepatoprotective flavonolignans from silymarin. Proc. Natl. Acad. Sci. 107(13): 5995-5999.

Skaria R, Sen S and Muneer PMA (2011) Analysis of genetic variability in rice varieties (Oryza sativa L) of Kerala using RAPD markers. Genet. Eng. Biotechnol. J. 24: 1-9.

Samu Z, Nyiredy S, Baitz-Gcs E, Varga Z, Kurtn T, Kinya Z and Antus S (2004) Structure elucidation and antioxidant activity of (-)-isosilandrin isoalted from Silybum marianum L. Chem. Biodiversity 1: 1668-1677.

Sneath PHA and Sokal RR (1973) Numerical Taxonomy: The principles and practice of numerical classification. San Francisco, California.

Sucher NS and Carles MC (2008) Genome-based approaches to the authentication of medicinal plants. Planta Med. 74: 603-623.

Um JY, Chung HS, Kim MS, Na HJ, Kwon HJ, KIM JJ, Lee KM, Lee SJ, Lim JP, Do KR, Hwang WJ, Lyu YS, An NH and Kim HM (2001) Molecular authentication of Panax ginseng species by RAPD analysis and PCR-RFLP. Biol. Pharm. Bull. 24(8): 872-875. 